\title{
Services Exports: An Evolution And Evaluation Of Thailand's Services Exports In The Context Of ASEAN-5
}

Sujinda Chemsripong, Naresuan University, Phisanulok, Thailand Amir Mahmood, University of Newcastle, NSW, Australia

\begin{abstract}
The services sector plays an important role in the economic transformation of a country. The growing tradability of services provides new challenges and opportunities to Thailand's services industries. Underpinning these challenges and opportunities is the competitiveness and export structure of the services sector. Thailand's current services export structure is a manifest of its relative specialisation based upon given resources, activities, and strategies. To assess the competitiveness of Thailand's services sector, the paper computes the Revealed Comparative Advantage (RCA) indices of Thailand's transport, travel, insurance, and financial services. Specifically, the paper evaluates the shifting export competitiveness of Thailand's services industries in the context of ASEAN-5. Among other factors, export competitiveness in services depends upon the height of market access barriers, targeted under GATS and AFAS. The paper analyses Thailand's service liberalisation scorecard in terms of its commitments to liberalise trade in services. Acknowledging the fact that the domestic, regional, and global trading environment is a necessary but not a sufficient condition for services firms to participate in international trade, the paper signifies the need to work on various industry, firm, and modespecific factors that underpin competitiveness of the Thai services industry.
\end{abstract}

Keywords: Services exports, Revealed Comparative Advantage (RCA), Thailand's services exports, ASEAN 5

\section{INTRODUCTION}

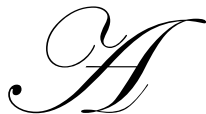

key factor in the economic transformation and structural change in both developing and developed countries has been the growing contribution of the services sector in economic growth, employment, and trade. Rising with a growth rate of 10 percent per annum, global trade in services stood at around two and half trillion US dollars in 2005, amounting to one-quarter of total world trade (WTO, 2006). The prime objective of this paper is to provide an evolution and evaluation of Thailand's services exports in the context of ASEAN-5, which include other four key ASEAN members-Singapore, Philippines, Malaysia, and Indonesia. Given the geographical and cultural proximity, the emergence of regional production networks, complementarities in factor endowments, and close economic integration under ASEAN Framework Agreement on Services (AFAS), it is important to evaluate export performance of Thailand's services industries in the context of other key ASEAN member economies.

The paper is organised into 6 sections. Section 2 highlights the structural transformation of Thailand's economy by evaluating the changing role of services sector in value added, trade, and employment during 19942004. The period selected to undertake the above exercise is fitting as it overlaps with trade liberalisation measures undertaken by Thailand under GATS and AFAS. Section 3 evaluates Thailand's services trade performance in relation to other key ASEAN member countries. In the absence of detailed data on services trade, the scope of this paper is limited to assessing Thailand's services export performance at an aggregated level. To assess export competitiveness, Section 4 carries out the "revealed comparative advantage" (RCA) analysis by computing RCA indices for transport, travel, insurance and financial, and other commercial services. This section also provides 
plausible generic determinants of service industries by mode of service delivery. One of the key stumbling blocks, whish is hampering WTO members to push to expand their services export, is the market access barriers. Trade liberalisation measures undertaken by ASEAN-5 as a part of their commitment under GATS and AFAS have important bearing on performance of these economies. Section 5 provides a comparative snapshot of trade liberalisation commitments undertaken by ASEAN-5 and relates this to possible implications for Thailand's services export potential. Section 6 draws conclusions from the study.

\section{SERVICES IN THAILAND'S ECONOMY}

In 1996, services contributed to 50 per cent to Thailand's GDP; 20 per cent to trade; and 30 per cent to total employment. By 2004, services share in value added in GDP stood at 46 per cent; 26 per cent for trade; and 35 per cent for employment. Among the ASEAN-5, Singapore has been the most service-oriented economy; with the services sector contributing 66 percent to GDP, 76 percent to trade, and 76 percent to employment in 2004 (Table 1). In terms of contribution of services to total trade, Thailand's is ranked third behind Singapore and Malaysia. It is clear that it will take deployment of considerable resources, change in resource allocation, and implementation of services-friendly business environment for Thailand to emulate Singapore's experience.

Table 1 Services in ASEAN-5 (\%)

\begin{tabular}{|c|c|c|c|c|c|c|}
\hline \multirow{2}{*}{ ASEAN Member } & \multicolumn{2}{|c|}{ Value Added in GDP } & \multicolumn{2}{|c|}{ Trade } & \multicolumn{2}{c|}{ Employment } \\
\cline { 2 - 7 } & 1996 & 2004 & 1996 & 2004 & 1996 & 2004 \\
\hline Indonesia & 40 & 41 & 10 & 18 & - & 44 \\
\hline Malaysia & 45 & 40 & 32 & 30 & 48 & 55 \\
\hline Philippines & 47 & 53 & 24 & 11 & 42 & $53^{\mathrm{a}}$ \\
\hline Singapore & 64 & 66 & 56 & 76 & 69 & 76 \\
\hline Thailand & 50 & 46 & 20 & 26 & 30 & 35 \\
\hline
\end{tabular}

Source: World Bank (2006), World Development Indicators, and Asian Development Bank, Key Indicators 2006: Measuring Policy Effectiveness in Health and Education,

Notes: ${ }^{\text {a }}$ figures for 2005

Thailand's commercial services sector has proved its reliance during recent times. During 1995-2005, which includes the financial crisis of the late 1990's, Thailand's services exports grew by 41 per cent. In value terms, this performance was second to Singapore (IMF, 2006). The broad category of "commercial services" encompasses, business services; communication services; construction and related engineering services; distribution services; educational services; environmental services; financial services; health related and social services; tourism and travel related services; recreational, cultural and sporting services; transport services; and other services that are not included elsewhere (WTO 2006).

To assess and evaluate Thailand's export competitiveness in the above services, a detailed disaggregated data for each of the above service industry is required. A detailed comparison between Thailand and other ASEAN members is, however, difficult to make due to the unavailability of data. Further, the existing data does not provide a complete picture regarding the share of each service category in the total export of commercial services. The available trade data on major service categories, such as transport services, travel services, insurance and financial services, and "other commercial" services, gives a broad picture of composition of trade in commercial services.

According to this broad categorisation, travel services contributed 53 per cent to Thailand's total export of commercial services in 2004. Indonesia, Malaysia, and the Philippines also exhibited similar trends in export of travel services. Another noticeable aspect of Thailand's services export structure is an increased contribution of transport services to export of commercial services, which increased from 17 per cent in 1995 to 23 per cent in 2004 (World Bank, 2006). While an increase in export of transport services indicates a concerted effort by Thailand to move into high value added services, the dominance of travel services indicates Thailand's services export structure is predominantly represented by low value added services. It is, however, important to note that Thailand's existing 
export structure is an outcome of the country's export competitiveness, underpinned by factor endowments, economic and institutional environment, and the level of technological sophistication.

\section{EXPORT COMPETITIVENESS OF THAILAND'S SERVICE INDUSTRIES:}

Unlike goods trade, there have been far few attempts to gauge the export competitiveness of services industries. Dihel, Eschenbach et al (2006) and (Langhammer 2004) have used the Revealed Comparative Advantage RCA) approach to assess the export competitiveness by computing RCA indices of services industries. The RCA index of a service industry is the ratio of its exports to the country's total services exports, divided by the ratio of world exports of this service to total world exports in services. An index of greater (less) than 1 implies the country is relatively more (less) specialised than the world average and thus, exhibits comparative advantage (disadvantage) in that service industry (Dihel, Eschenbach et al. 2006).

The exercise to evaluate export competitiveness has been made difficult due to peculiar characteristics of services, which result in services being exported through various modes of delivery. The export data pertaining to different modes of delivery, however, fails to capture the full extent of exports undertaken by a service industry through all modes of delivery. These delivery modes include: a) cross bordersupply-Mode1; b) consumption abroadMode 2; c) commercial presence-Mode 3; and d) movement of natural persons-Mode 4. For example, available services trade data do not capture export of services through Mode 3 and Mode 4.

To analyse the shifting export competitiveness of Thailand's service industries in the context of ASEAN-5, the study computes the RCA indices for 1995 and 2004 (Table 2). These industries include: transport, travel, insurance and financial, and "other commercial" services. In the present context, the category of "other commercial services" includes: business services; communication services; construction services; distribution services; educational services; environmental services; health services; recreational, cultural and sporting services; and other services not included elsewhere.

Table 2 Revealed Comparative Advantage (RCA) of ASEAN-5 in Services Trade (1995-2004)

\begin{tabular}{|c|c|c|c|c|c|c|c|c|}
\hline \multirow{2}{*}{ ASEAN Member } & \multicolumn{2}{|c|}{ Transport Services } & \multicolumn{2}{c|}{ Travel Services } & \multicolumn{2}{c|}{$\begin{array}{c}\text { Insurance \& Financial } \\
\text { Services }\end{array}$} & \multicolumn{2}{c|}{$\begin{array}{c}\text { Other Commercial } \\
\text { Services }\end{array}$} \\
\cline { 2 - 9 } & 1995 & 2004 & 1995 & 2004 & 1995 & 2004 & 1995 & 2004 \\
\hline Indonesia $^{a}$ & - & 0.71 & 2.97 & $2.69 *$ & - & 0.01 & 0.06 & 0.12 \\
\hline Malaysia $^{\text {Philippines }}{ }^{\mathrm{b}}$ & 0.81 & 0.79 & 1.06 & 1.69 & - & 0.43 & 1.26 & 0.73 \\
\hline Singapore & 0.48 & 1.13 & 1.71 & 1.69 & 0.29 & 0.14 & 0.89 & 0.58 \\
\hline Thailand & 1.11 & 1.50 & 0.85 & 0.41 & 1.33 & 1.43 & 1.00 & 1.05 \\
\hline
\end{tabular}

Source: Author's computation; World Bank (2006), World Development Indicators

Notes: ${ }^{\text {a }}$ The latest year is $2003 .{ }^{\mathrm{b}}$ The earliest year is 1999.

As highlighted in Table 5, there have been changes in the revealed comparative advantage patterns of Thailand and other ASEAN service industries during 1995-2004. For instance: a) the extent of Thailand's comparative disadvantage has declined, with the RCA index increasing from 0.63 in 1995 to 0.96 in 2004; Thailand has improved its export competitiveness in travel services, with the RCA index rising from 1.67 in 1995 to 1.83 in $2004 ; c)$ there has been a deterioration in the level of export competitiveness of insurance and financial services; and d) the category of "other commercial services" has also witnessed a decline in its export competitiveness.

In comparison with other ASEAN countries, it is evident that Indonesia, Malaysia, and the Philippines have also shown an improvement in relatively labour intensive travel services. In the case of transport services, Philippines and Singapore have also shown improvement with a steady rise in the RCA indices. It is evident that Thailand transport services industry is facing stiff challenges from Malaysia and Singapore. 
With the exception of Singapore that historically acted as a hub of regional financial services industry, trade in insurance and financial services is a relatively new phenomenon in the ASEAN region. It is important to note that while Malaysia, the Philippines and Thailand exhibit revealed comparative disadvantage in this broad service category, they are making concerted efforts to follow Singapore's performance in high value added services export. This observation confirms earlier results that countries such as Malaysia and Thailand are developing capabilities to acquire comparative advantage in sophisticated services (Dihel, Eschenbach et al. 2006).

\section{DETERMINANTS OF SERVICES EXPORTS AND DELIVERY MODES}

The estimates of revealed comparative advantage provide a snapshot of Thailand's export competitiveness with regards to other ASEAN members in selected services. This analysis, however, does not explain the extent of specialisation or comparative advantage by mode of delivery within the same industry as an industry may exhibit comparative advantage or disadvantage in some or all four modes of delivery. Consequently, the determinants of services export depend upon not only the factors that underpin comparative advantage of a country or a region in "producing" a service, but also on factors that facilitate the delivery of services through various modes (Newfarmer, Nielson et al, 2006). These delivery mode-specific determinants include:

A country's advanced, open, and service oriented economic structure; its cultural proximity to services export markets; liberal trade regime; and domestic policy environment. For instance, Thailand's economic structure and domestic policy environment have played key roles in making the country a hub of healthcare services education through e-learning (Mode 1), increased in-flow of patients (Mode 2), the opening up of branch hospitals of foreign hospitals (Mode 3), and off-shore delivery of medical services by Thai local delivery of education programs by foreign academics (Mode 4).

As noted above, trade regime or access to global markets is an increasingly important driver of services export. Given the emerging role of the General Agreement on Trade in Services (GATS) in setting the rules of the game, it is evident that issues involving enhancing trade in services and internationalisation of services industries in the ASEAN region cannot be addressed adequately without a clear understanding of the impact of GATS on services industries.

\section{THAILAND'S SERVICES TRADE LIBERALISATION COMMITMENTS IN THE ASEAN CONTEXT}

Under GATS, the salient features governing the conduct of Thailand in services trade include unconditional commitments or general obligations and the binding commitments. The unconditional commitments involve: a) most-favoured-nation (MFN) treatment that bans all types of discrimination between service providers from different countries; b) transparency; c) dispute settlement; and d) issues regarding monopoly. All WTO members are obliged to adhere to the above obligations across all services sectors. Of course, the most important one is the MFN treatment. The conditional commitments, which are attached to national schedules and are sector-specific, include: a) commitments made by the members concerning market access; and b) national treatment. National treatment requires equal treatment to national and foreign service providers. Whereas, commitments under market access specifies the degree and the extent of market access bestowed in a particular service sector While the submission of such a schedule is required, Thailand is not obliged to assume commitments in a particular sector, providing flexibility to members to adjust or set the level of commitments based on given constraints or objectives (United Nations 2002), (Knight 2002).

Sector-specific bindings provide a formal and explicit set of commitments regarding the level of openness in that particular sector (Belsky, Lie et al. 2004). Under GATS, the specific commitments may be invoked with regard to four alternative modes of supply (e.g., cross border-Mode 1; consumption abroad-Mode 2; commercial presence-Mode 3; and movement of natural persons-Mode 4). The commitments made by the WTO members regarding market access issues in services trade differ from one service sector to another. Further, the height of market access barriers vary across the four modes within the same services sector. 
Thailand is the leading ASEAN-5 member in terms of sectoral commitments under GATS. The commitments by Thailand are closely followed by Malaysia, Singapore, Indonesia, and the Philippines (Table 3).

Table 3 Thailand's \& ASEAN: Commitments under GATS

\begin{tabular}{|l|c|c|c|c|c|c|c|c|c|c|c|c|c|}
\hline \multicolumn{1}{|c|}{ Country } & 1 & 2 & 3 & 4 & 5 & 6 & 7 & 8 & 9 & 10 & 11 & 12 & Total \\
\hline Indonesia & Yes & Yes & Yes & - & - & - & Yes & - & Yes & - & Yes & - & 6 \\
\hline Malaysia & Yes & Yes & Yes & - & - & - & Yes & Yes & Yes & Yes & Yes & Yes & 9 \\
\hline Philippines & & Yes & & - & - & - & Yes & - & Yes & - & Yes & - & 4 \\
\hline Singapore & Yes & Yes & Yes & - & - & - & Yes & - & Yes & Yes & Yes & - & 7 \\
\hline Thailand & Yes & Yes & Yes & Yes & Yes & Yes & Yes & - & Yes & Yes & Yes & - & 10 \\
\hline
\end{tabular}

Source: Adapted from WTO (WTO 2006).

Notes: 1 = Business services; $2=$ Communication services; $3=$ Construction and Related Engineering Services; $4=$ Distribution Services; 5= Educational Services; 6= Environmental Services; $7=$ Financial Services; $8=$ Health Related and Social Services; $9=$ Tourism and Travel Related Services; $10=$ Recreational, Cultural and Sporting Services; $11=$ Transport Services; $12=$ Other Services not Included Elsewhere

As noted in Table 3, Thailand has shown relatively more flexibility in liberalising services sector than some of the other ASEAN members. Interestingly, these sectors are prominent and/or becoming noticeable in terms of their revealed comparative advantage. In the ASEAN context, the least committed sectors are distribution; educational; environmental; health related and social; and other services not included elsewhere (Table 3). The lack of commitment is a manifestation of lack of consensus among the WTO members, including some of the ASEAN-5 members to reach an agreement. Given the difficulties in reaching such a consensus in the context of ongoing trade negotiations under WTO, Thailand, and other ASEAN members have resorted to regional liberalisation in services trade through ASEAN Framework Agreement on Services (AFAS).

The objectives of AFAS are to: complement efforts to liberalise trade through ASEAN Free Trade Area (AFTA); enhance the competitiveness of ASEAN services industries in the global markets; to improve services sector synergies among the member states; reduce protection on services trade among ASEAN that goes further than that undertaken in GATS by the ASEAN members, i.e., GATS-plus commitments by the member states (Hiong 2004).

Three successive rounds of negotiations among the ASEAN members have resulted in 4 packages of commitments in 7 services sectors/sub sectors, which include:

1. Air transport (i.e., sales and marketing of air transport services, computer reservation, aircraft repair and maintenance).

2. Business services (i.e., IT services, accounting, auditing, legal, architecture, engineering, market research).

3. Construction (i.e., construction of commercial buildings, civil engineering, installation works, rental of construction equipments).

4. Financial services (i.e., banking, insurance, securities and broking, financial advisory, consumer finance).

5. Maritime transport (i.e., international passenger and freight transport, storage and warehousing).

6. Telecommunication (i.e., public telephone services, mobile phone services, business networks services, data and message transmission, etc).

7. Tourism (i.e., hotel and lodging services, food serving, tour operator, travel agency) (Thanh and Bartlett 2006).

To date, the key outcome of AFAS has been an increased depth and scope of ASEAN existing commitments under GATS. Further commitments in the areas of business, transport, financial, travel, construction, 
and communication services complement the sectoral commitments made by ASEAN members ${ }^{1}$. These commitments are made with a view to reach the target of free trade in services among ASEAN members by 2015.

A comparison of sectoral commitments, excluding "other services", shows that Thailand, Indonesia and the Philippines have gained by intra-ASEAN services liberalisation by expanding the scope of their sectoral coverage. On the other hand, some of the ASEAN-5 that exhibited extensive sectoral coverage under GATS, such as Malaysia and Singapore, benefited marginally under the AFAS sectoral negotiations (Table 4).

There is no doubt that Thailand has extended the sectoral commitments to facilitate intra-ASEAN services trade, the depth of these trades liberalisation, measured by the extent to which these commitments are bound, however remain shallow. However, this is also true for other members of ASEAN-5. Further, the transparency and predictability of these commitments, and presence of unbound barriers to services trade, have worked as drag factors in achieving full liberalisation potential of ASAF (Thanh and Bartlett 2006). This potential includes both an expansion of inter-industry as well as intra-industry trade in services. A move in this direction will help boost the efficiency of Thailand's services sector even further.

Table 4 ASEAN Sectoral Coverage: GATS and AFAS (4 digit- Central Product Classification Code)

\begin{tabular}{|c|c|c|c|c|c|c|c|c|c|c|c|c|c|c|}
\hline \multirow{5}{*}{$\begin{array}{l}\text { ASEAN } \\
\text { Member }\end{array}$} & \multicolumn{2}{|c|}{$\begin{array}{c}\text { Air } \\
\text { transport }\end{array}$} & \multicolumn{2}{|c|}{$\begin{array}{l}\text { Business } \\
\text { services }\end{array}$} & \multicolumn{2}{|c|}{ Construction } & \multicolumn{2}{|c|}{$\begin{array}{c}\text { Financial } \\
\text { services }\end{array}$} & \multicolumn{2}{|c|}{$\begin{array}{l}\text { Maritime } \\
\text { transport }\end{array}$} & \multicolumn{2}{|c|}{ Telecommunication } & \multicolumn{2}{|c|}{ Tourism } \\
\hline & $\mathrm{G}$ & $\mathrm{A}$ & $\mathrm{G}$ & $\mathrm{A}$ & $\mathrm{G}$ & $\mathrm{A}$ & $\mathrm{G}$ & $\mathrm{A}$ & $\bar{G}$ & $\mathrm{~A}$ & $\mathrm{G}$ & $\mathrm{A}$ & $\mathrm{G}$ & $\mathrm{A}$ \\
\hline & A & $\mathrm{F}$ & A & $\mathrm{F}$ & A & $\mathrm{F}$ & A & $\mathrm{F}$ & A & $\mathrm{F}$ & A & $\mathrm{F}$ & A & $\mathrm{F}$ \\
\hline & $\mathrm{T}$ & A & $\mathrm{T}$ & A & $\mathrm{T}$ & A & $\mathrm{T}$ & A & $\mathrm{T}$ & A & $\mathrm{T}$ & A & $\mathrm{T}$ & A \\
\hline & $\mathrm{S}$ & $\mathrm{S}$ & $\mathrm{S}$ & $\mathrm{S}$ & $\mathrm{S}$ & $\mathrm{S}$ & $\mathrm{S}$ & $\mathrm{S}$ & $\mathrm{S}$ & $\mathrm{S}$ & $\mathrm{S}$ & $\mathrm{S}$ & $\mathrm{S}$ & $\mathrm{S}$ \\
\hline Indonesia & - & 2 & 15 & 17 & 27 & 48 & 10 & 10 & 2 & 7 & 5 & 5 & 2 & 6 \\
\hline Malaysia & - & 3 & 34 & 57 & 46 & 46 & 14 & 14 & 3 & 4 & 6 & 6 & 12 & 16 \\
\hline Philippines & 3 & 5 & - & 19 & - & 48 & 13 & 14 & 4 & 4 & 3 & 4 & 4 & 6 \\
\hline Singapore & - & 3 & 25 & 28 & 48 & 48 & 10 & 10 & 2 & 3 & 5 & 6 & 11 & 11 \\
\hline Thailand & 7 & 7 & 39 & 46 & 24 & 48 & 9 & 9 & 9 & 12 & 11 & 19 & 5 & 8 \\
\hline
\end{tabular}

Source: Adapted from (Thanh and Bartlett 2006). Authors'computations.

Note: Sectoral coverage involving "other services" is excluded from Table 4.

\section{CONCLUSIONS}

Thailand's future economic growth and wellbeing depends upon the extent of which services sector contributes to output, employment, and exports. However, not all services are trade sensitive and/or exhibit comparative advantage. There is a need for specialisation and movement towards contesting dynamic and potential growth services in global markets. Some of these dynamic sectors include: informatics; digital media; e-business; health sciences; education and training; logistics management services; agriculture and marine services; and professional services (consultancy, engineering, architecture etc) (Whelan 2005). While all the above services indicate high global world demand, Thailand needs to be selective while formulating industry-specific strategies to promote service exports. Industry-specific drivers alone, however, are necessary but not sufficient for exportoriented servisisation of Thailand's economy. Complimentary global, national, and firm-specific drivers are equally important. It is the interaction of these four factors that helps services firms reach their export potential.

\footnotetext{
${ }^{1}$ Following GATS negotiation modalities, ASEAN members have followed the request and offer approach. The approach permits two or more ASEAN members to negotiate sectoral liberalisation commitments. Other members, however, can become part of the agreements at a later date as long as they make similar offers that are acceptable to the original ASEAN members (Thanh, V. T. and P. Bartlett (2006). Ten Years of ASEAN Framework Agreement on Services

(AFAS): An Assessment.
} 


\section{REFERENCES}

1. Asian Development Bank, Key Indicators 2006: Measuring Policy Effectiveness in Health and Education, Manila: Asian Development Bank

2. $\quad$ Belsky, L., R. Lie, et al. (2004), "The General Agreement On Trade In Services: Implications For Health Policymakers." Health Affairs 23(3): 137-146.

3. Dihel, N, Eschenbach, F, and Shepherd, B. (2006), South-South Services Trade. Paris, OECD, Available online $\langle$ http//www.oecd.org/trade $>$

4. Hiong, T. T. (2004). Towards Free Flow of Trade in Services: The ASEAN Experience. WTO/ESCAP Regional Workshop on Trade in Services Negotiations, Dhaka, Available online < http://www.unescap.org/tid/projects/gats04\%5Fs3tan.pdf>

5. International Monetary Fund (2006), International Financial Statistics, Washington DC: International Monetary Fund

6. Knight, J. (2002), 'Trade in Higher Education Services: The Implications of GATS', The Observatory on Borderless Higher Education, Available online < http://www.obhe.ac.uk/products/reports/publicaccesspdf/March2002.pdf>

7. Langhammer, R. (2004), 'Revealed Comparative Advantages in Service Trade of the USA, EU, and Japan. What Do They Tell Us?,' Journal of World Investment and Trade 5(6): 887-96.

8. Newfarmer, R., J. Nielson, and Zhao, Longyue (2006), 'Domestic and Regional Policies to Promote Services Trade in China', MOFCOM-WBI SeminarTrade in Services: Global Trade and China's Position, Washington DC: World Bank, Available online <www.worldbank.org>

9. Ramcharran, H. (1997), 'Trade Liberalization in Services: An Analysis of the Obstacles and the Opportunities for Trade Expansion by US Law Firms', Multinational Business Review 7(1): 27.36.

10. Thanh, V. T. and P. Bartlett (2006). Ten Years of ASEAN Framework Agreement on Services (AFAS): An Assessment, Available online < http://www.aadcp-repsf.org/docs/05-004-FinalReport.pdf>

11. United Nations (2002), Manual on Statistics of International Trade in Services. New York, Available online $\langle$ http://unstats.un.org/unsd/tradeserv/Papers/m86 english.pdf >

12. Whelan, J. F. (2005), 'Export of Services-Hype or High Potential' Executive Forum on National Export Strategies- Export of Services: Hype or High Potential? Implications for Strategy Makers, Montreux, Switzerland, Available online < Available online < http://www.intracen.org/execforum/ef2005/montreux/Country-Papers $>$

13. World Bank (2006), World Development Indicators, Washington DC

14. WTO (2006), International Trade Statistics, 2006, Geneva: WTO, Available online http://www.wto.org 


\section{NOTES}

